\title{
Numerical Study about Improving the Proficiency of an Earth Air Heat Exchanger System (EAHE) Employing Ground Cover Material
}

\author{
Haitham Alkhalaf, Md Najib Ibrahim, and Wanglin Yan
}

\begin{abstract}
This research presents an investigation into the performance of Earth Air Heat Exchanger (EAHE) in Malaysian climate. The passive cooling technology, where the ground is used as a heat sink to produce cooler air, it is an emerging of area of interest in Malaysia. This system is an important concept of sustainable design for Green House which enhance energy saving and reducing of Green House Gases emission. The aim of this study is to find the best ground cover in improving the (EAHE) proficiency through thermal model using computer simulation. The pipe which was used in thermal model have same parameters of real case which were 3 -inch diameter and the material of pipe was PVC, the velocity of flow air was $1 \mathrm{~m} / \mathrm{s}$, the pipe was buried in $4 \mathrm{~m}$ depth and had $50 \mathrm{~m}$ length. The performance of the EAHE was simulated using loam, clay, sand, silty clay, sandy clay loam as back fill material. It was found that sandy soil is the best ground cover material.
\end{abstract}

Index Terms-Earth air heat exchanger, ground cover, passive technology.

\section{INTRODUCTION}

Saving energy is one of the most important global challenges in nowadays. In the meantime, environmental concerns drive this trend much further. In order to reduce greenhouse gas (GHG) emissions, which are considered to be reason of global warming and sources of pollution, the Kyoto protocol set specific targets for reduction of $\mathrm{CO}_{2}$ emissions. This situation has encouraged two important initiatives. First, efforts on producing electricity with higher efficiency; Second, on using electricity with higher efficiency and more efficient use of energy not only reduces the consumption of electricity, but also lowers the consumption of primary energy sources.

Buildings, whether residential or commercial, mainly use energy to attain comfort for their residents. Although comfort includes visual and ergonomic, the main concern is about thermal. Air conditioning used to maintain comfort nowadays but utilities high energy. In order to reduce energy utilization of buildings, several passive techniques are introduced in attaining thermal comfort.

This paper focuses on one of passive cooling technology which uses the earth as a heat sink. This technology will be examined in tropical weather, the usage of EAHE system can

Manuscript submitted on June 4, 2017; revised August 13, 2017. Haitham Alkhalaf and Wanglin Yan are with Graduated School of Media \& Governance, Keio University, Japan (e-mail: haitham@sfc.keio.ac.jp, yan@sfc.keio.ac.jp)

Md Najib Ibrahim is with Faculty of Architecture \& Environmental Design, International Islamic University Malaysia (e-mail: drnajib@iium.edu.my). be applied into conditioning system through three primary methods: direct, indirect, and isolated method.

EAHE system takes advantage of the high thermal inertia of the soil where at sufficient depth the ground temperature is lower than the outside temperature in summer. The fresh air is drawn inside the EAHE system to cool it before carry it out inside the building. EAHE system can supply conditioned fresh air to air-conditioning units which could reduce value percentage of electricity consumption in the building [1].

\section{A. Passive Design in Malaysia's Building}

The extreme growth in using air condition system for cooling the buildings especially in summer causes severe energy crisis in developing countries during last two decades. That increases energy consumption and global warming.

Passive cooling systems depend on non-mechanical methods to achieve the thermal comfort inside building and reduce the impact of buildings on the environment. Passive cooling techniques can save energy in buildings by decreasing the required cooling load [2].

With global concerns on the environment and sustaining the world resources for the future generations, Malaysia has embarked on initiatives for sustainable development. Malaysia's framework for energy development in terms of energy diversification and efficient utilization as well as emphasis on sustainable environmental started when the National Energy Policy 1979 (NEP79), National Depletion Policy 1980 (NDP80), Four Fuel Diversification Policy 1981 (4FDP81) and Fifth Fuel Policy 2000 (5FP2000) were formed [3].

The Green Building Index (GBI) has been promulgated by Malaysian Architect Association and the Association of Consulting Engineers Malaysia (ACEM). Since its inception in 2009, it has been applied on voluntary basis by developers and alike for residential and commercial buildings. Recently it has also been extended to the manufacturing buildings. The Malaysian government has shown its support through many incentives for the implementation of GBI. There are indications to make GBI mandatory [3].

Malaysia has begun to embark on the green building practices. With the Malaysian building sector consuming nearly $8,000 \mathrm{GWh}$ of energy in 2008 , if nothing is done to optimize energy utilization, the sector will continue to contribute significantly towards the greenhouse gas emissions (GHG) [3]. The Malaysian government has launched a few projects to act as a demonstration, educational and enhance public awareness programs regarding to energy efficiency and the use of sustainable energy in buildings.

Malaysia Green Technology Corporation office building or formerly known as Malaysia Energy Center (PTM) is one 
of these projects, which is situated in Bandar Baru Bangi. The design of the building is fully based on zero energy building (ZEB) concept. The project was completed in the year 2007; however, the office building is still unable to fulfill its energy needs [4].

According to Building Sector Energy Efficiency Project (BSEEP) report, it indicates that there are barriers towards the wide spread implementation of energy efficiency for buildings. The financial barrier is the most significant barrier to energy efficiency in Malaysia's building sector. So, the awareness of designer plays the important key role to overcome this issue by employing the energy efficiency design practices [5].

For Malaysia as tropical climate, the ground cover can be a passive cooling technique for cooling building. Because of the difference between the ambient temperature and the underground temperature that will give a considered saving in cooling load and saving energy [6].

\section{EARTH AIR HEAT EXCHANGER (EAHE) SYSTEM}

Earth-Air Heat Exchangers is defined as "a system of pipes that utilize the earth near constant temperature in order to cool or heat air or other fluids that move through the pipes. It can be used as a passive cooling or heating system for residential, commercial, industrial or agricultural applications" [7].

In certain areas or applications, EAHE system can be used as alternative system to conventional air condition system that could possibly reduce energy consumption [1], [8], [9].

The using of EAHE system becomes common as a passive technique in buildings to reduce the required cooling or heating demand. But this implementation requires large surface of area for their installation and using of large diameter tubes to reduce the pressure drop [10]. EAHE system is used as a passive technique from long time ago for heating and cooling usage [11].

By using Energy Plus program and experimental data, EAHE system examined to achieve energy saving in residential building for different polish climate conditions [12]. Since the air is drawn through EAHE system usually cools and dehumidifies hot ambient air also it can preheat the cold ambient air [13], [14].

As shown in Fig. 1, EAHE system consists of a pipe layout through underground where, the ambient air is pushed by means of an air system such as a fan or an extractor to be injected inside the room. Therefore this system is not $100 \%$ a passive technique [7].

The mechanism of this system which is heat exchange between air and walls of the pipe. It helps to reduce the temperature of the air during the summer or raise it during the winter.

The assessment of EAHE system' proficiency can be calculated via measuring the coefficient of performance (COP) [15]-[17]. COP calculates by dividing the energy output of the EAHE by the electrical energy required to run the blower fan, at a specific temperature. The higher the COP means more efficient the EAHE. EAHE system is able to reach an average COP of 6.32 and peak of 6.89 during the heating tests despite occasional heat losses to the surrounding soil [15]. For instance, an open and closed loop systems, the
COP can be as high as 10 . Conventional air conditioning systems have average year-round COPs of about 2.0.

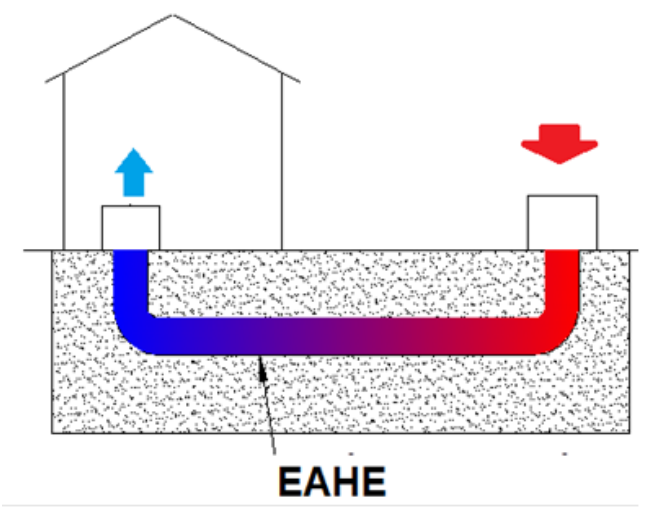

Fig. 1. Earth air heat exchanger.

If the EAHE system supported with a heat pump it will improve the COP and the capacity of the heat pump [18]. Also the velocity of air flow improves the EAHE COP by 1.9 to 2.9 for velocity ( 2 to $5 \mathrm{~m} / \mathrm{s}$ ) [19].

EAHE system can reduce the operative temperature inside the building by average $1.9^{\circ} \mathrm{C}$. Therefore, reduce cooling energy load by about $595 \mathrm{kWh}$ [12]. Through simple comparison between houses coupled with EAHE system and another houses without EAHE, it shows how EAHE can achieve reduction by more than $7.5^{\circ} \mathrm{C}$ [20].

\section{A. Earth Air Heat Exchanger's Application}

The EAHE has many applications in different types of buildings and in different climate [21]-[25]. It has been applied in agricultural field [17] or residential building [15], school [22], house family and office room [26].

(EAHE) generally, cannot be full air condition system to provide indoor thermal comfort, but it can achieve indoor thermal comfort by an adequate combination of building thermal mass and (EAHE) [27], [28]. but it works as refreshing or ventilation system which supports classic air condition system to reduce the consumed energy [29]-[31].

EAHE can be used in different climate zones such as arid climate [14], [15], [28], hot and dry climate [31], Mediterranean climate [16], [22], tropical climate [17], and either for cooling in summer or heating in Winter [22], [27], [32].

\section{B. Earth Air Heat Exchanger's Parameters}

There are various parameters which control EAHE system's performance. Every parameter effects on EAHE performance in different way than other. For instance, the thermal performance and pressure drop both grow with length. Smaller tube diameters give better thermal performance, but also larger pressure drop. So he suggests using tubes in parallel both lower pressure drop and rise thermal performance can be achieved [10].

There are many options to improve the efficiency of EAHE system by design optimum value of parameters. one of these options is to install deep and long earth tube with a lower air velocity and smaller radius [33].

Using a numerical model enables to find out the best parameters for best performance of EAHE for some implementations such as house family and office room [26].

The pipe material is essential factor to enhance a good heat transfer between air and ground cover through the pipe' wall. 
The thermal properties of the pip is the most important criteria in determine the material of pipe [7]. It mostly consists of metal, concrete or plastic buried pipes [12]. On other hand, some researchers conclude through analysis the performance of EAHE system that the performance is not affected by the material type so it is better to choose cheaper one [19].

The length of pipe has main role in improving the EAHE efficiency but this length cannot be open limit because of the pressure drop. An EAHE with several ducts will be more efficient than a single pipe expands the same length [1].

It is essential principle to install the pipe under consider depth to keep it away from the surface temperature. therefore, the pipes should be buried in the soil under $1 \mathrm{~m}$ from the free surface in order to eliminate surface effects such as temperature variation, radiation, snow and rainfall [34]. There is no big difference between $2 \mathrm{~m}$ and $3 \mathrm{~m}$ but the cost of installation can be high. Also the thermal potential did not have a significantly increase for depths higher than $3 \mathrm{~m}$ [8].

Diameter of pipe has clear effect on EAHE system performance through demonstrating the air flow. The direct role of the pipe's diameter on volume flow and the velocity [7]. The increasing of tube diameter causes pressure lose therefore the saving of energy will be effected. On other hand the decrease of the pipe diameter leads to high pressure difference and high energy consumption by the fan.

Air velocity through underground pipes determines the volume of conditioned air inside building also control the cooling capacity [14]. Also the air condition at the inlet of (EAHE) can affect the thermal performance [35].

The installation plan of (EAHE) system can affect the capacity of energy saving and the total cost of (EAHE) installation [36].

In EAHE system; the soil condition or soil temperature plays the main role in heat transfer mechanism [32]. The soil works as a tank where tubes located inside and heat transfer carries out. Solar radiation has a huge impact on the temperature of the soil [9], [17]. The amount of heat conducted and diffused in various form differs from one soil type to another [13]. Many factors control this process such as Local soil conditions, soil moisture, tube depth, and other site-specific factors [21]. The ground cover has main role to determine the fluid outlet temperature through soil thermal conductivity [34]. Condition of soil and weather of particular location have to be consider before installing EAHE system that the earth tube will perform differently under different weather and soil conditions [33].

\section{GROUND COVER}

Many factors affect ground cover in EAHE system such as: The density, heat capacity and degree of compaction [26]. The presence of water in the soil also plays a consider role in ground cover properties. It is proven by using a numerical model that the groundwater level and soil moisture plays important role in soil temperature [26].

The heat transfer characteristics of the soil in the ground cover can be improved by using backfill material [34]. And best performance can be obtained by using wet and heavy soil [29].

The soil surrounded the buried pipes called ground cover which is the most essential parameter affecting design and performance of ETHE system [37]. Ground cover's temperature varies with soil type, depth, moisture content, time of year, and geographic Location [21] as shown in Fig. 2. This figure compares the cooling potential of EAHE system with different cover materials. Maximum cooling potential occurs at $2.00 \mathrm{pm}$.

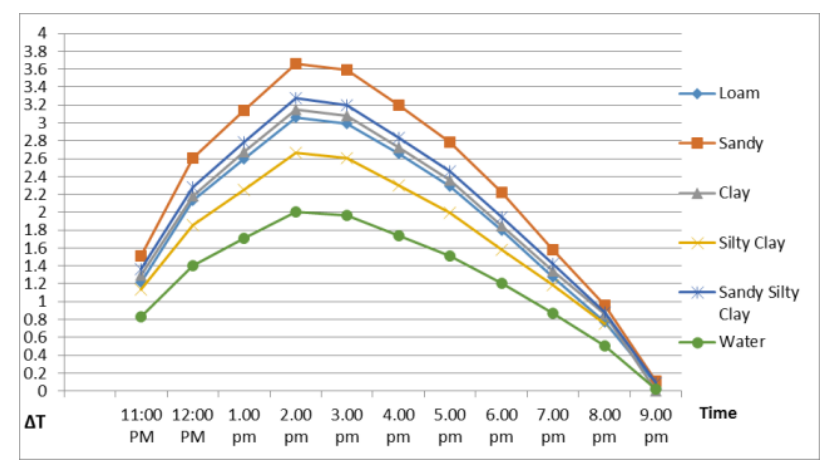

Fig. 2. Effect of Ground Cover on cooling potential $(\Delta \mathrm{T})$.

In the properties of soil, we have to distinguish two terms to understand the EAHE technology. First is a soil's thermal capacity which can be determined based on the dry soil properties and water properties, second one is a soil's thermal conductivity which is related on the density, quartz content and porosity [7]. The thermal conductivity of soil plays an essential role in a soil's capacity to maintain heat.

\section{A. Ground Heat Transfer Mechanisms}

To understand the ground heat transfer mechanism, it is necessary to illustrate the all variable and factors which affect and conduct this mechanism. Whereas the influence of trickling water or geothermal energy neglected, the incoming solar radiation and the of radiation exchange between the ground and the sky have to be consider [38].

On other hand absorption of the solar radiation depends on the ground cover and color, while the long wave radiant loss depends on soil surface temperature. The net radiant balance between solar gain and long-wave loss is usually positive in summer and negative in winter. This causes heat to flow down from the surface into the ground summer and upward to the surface during the winter. The net radiant balance also determines the relationship between the averages of the earth surface and the ambit temperatures. By shading the soil in summer while partially exposing it to the winter, for example, with deciduous trees, it is possible to lower the ground temperature in summer to a greater extent.

\section{B. Ground Thermal Properties}

The performance of an EAHE is directly related to the thermal properties of the ground. The ground has thermal properties that give it a high thermal inertia. The heat transfer mechanisms in soils are: conduction, convection and radiation. Conduction occurs throughout the soil but the main flow of heat is through the solid and liquid constituents. Convection is usually negligible. Radiation is important only in very dry soils, with large pores, when the temperature is high. Therefore, the main parameters influencing the thermal behavior of the soil are the thermal conductivity and heat capacity can be jointly expressed under the term of thermal diffusivity as in equation (1): 


$$
\alpha=\frac{K s}{\rho s . C s}
$$

where $\alpha$ : thermal diffusivity

$K s:$ is the thermal conductivity

$\rho s$ : the density and

Cs: the specific heat of the soil Thermal diffusivity determines the thermal behavior of the soil.

Therefore, soil thermal conductivity is the most important property parameters. A lot of complicated problem involved in heat transfer between buried pipe and soil in (EAHE), such as freezing and thaw of soil, flow of groundwater, simultaneous conduction of heat and wet etc., it can be simplified by using an equivalent thermal conductivity of soil, which can be obtained by measuring and analyzing through experiment [39].

It is necessary for the ground cover surrounded the buried tube to have a good contact with tube's wall by means of various types of material such as loam, clay or sand. These kinds of soil are also suitable for a correct tube installation [29]. The wet and heavy soil is recommended as a best ground cover which enhances high energy performance.

\section{RESEARCH METHODOLOGY}

This research is an extension of previous field experimental study on (EAHE) system which is constructed in International Islamic University Malaysia Gombak Campus in Kuala Lumpur Malaysia [40]. The experimental study did not investigate the role of ground cover. Therefore, this paper depends on some of the parameters of previous field experiment and some parameters from other similar study [7].

This research will use computer simulation to investigate the role of ground cover using ANSYS Fluent to simulate a numerical investigation on (EAHE) through a thermal model.

ANSYS Fluent software were used by many researchers to determine the role of underground soil and thermal conductivity pipes in cooling of building rooms using (EAHE) system [6], [19], [31]. Also the computational fluid dynamics (CFD) code of ANSYS FLUENT is used to provide basic knowledge of heat transfer in Earth-Air Heat Exchanger (EAHE) [41].

\section{A. Data \& Parameters}

TABLE I: THE TEMPERATURE OF THE WHOLE TYPICAL SUMMER DAY ON

\begin{tabular}{l|lllll}
\multicolumn{7}{c}{$12 \mathrm{TH}$ JUNE } \\
\hline Time & $T_{a m}\left({ }^{\circ} \mathrm{C}\right)$ & $T_{a m}(\mathrm{~K})$ & Time & $T_{a m}\left({ }^{\circ} \mathrm{C}\right)$ & $T_{a m}(\mathrm{~K})$ \\
\hline $1.00 \mathrm{am}$ & 26.64 & 299.79 & $1.00 \mathrm{pm}$ & 32.68 & 305.83 \\
$2.00 \mathrm{am}$ & 26.48 & 299.63 & $2.00 \mathrm{pm}$ & 33.28 & 306.43 \\
$3.00 \mathrm{am}$ & 26.15 & 299.3 & $3.00 \mathrm{pm}$ & 33.19 & 306.34 \\
$4.00 \mathrm{am}$ & 25.69 & 298.84 & $4.00 \mathrm{pm}$ & 32.75 & 305.9 \\
$5.00 \mathrm{am}$ & 25.19 & 298.34 & $5.00 \mathrm{pm}$ & 32.29 & 305.44 \\
$6.00 \mathrm{am}$ & 25.06 & 298.21 & $6.00 \mathrm{pm}$ & 31.66 & 304.81 \\
$7.00 \mathrm{am}$ & 25.10 & 298.25 & $7.00 \mathrm{pm}$ & 30.96 & 304.11 \\
$8.00 \mathrm{am}$ & 25.16 & 298.31 & $8.00 \mathrm{pm}$ & 30.26 & 303.41 \\
$9.00 \mathrm{am}$ & 26.58 & 299.73 & $9.00 \mathrm{pm}$ & 29.19 & 302.34 \\
$10.00 \mathrm{am}$ & 28.71 & 301.86 & $10.00 \mathrm{pm}$ & 27.95 & 301.1 \\
$11.00 \mathrm{am}$ & 30.88 & 304.03 & $11.00 \mathrm{pm}$ & 26.69 & 299.84 \\
$12.00 \mathrm{pm}$ & 32.08 & 305.23 & $12.00 \mathrm{am}$ & 26.08 & 299.23 \\
\hline
\end{tabular}

The data and parameters used in this research are combination of those used and collected in previous work and the authors own parameter based on literature review.

The pipe which is used in thermal model has same parameters of installed system in IIUM campus. It is 3-inch diameter and the material of pipe is PVC, the velocity of flow air is $1 \mathrm{~m} / \mathrm{s}$, the pipe is buried in $4 \mathrm{~m}$ depth and has $50 \mathrm{~m}$ length. There are other physical properties such as:

Density $\rho=1400 \mathrm{Kg} / \mathrm{m}^{3}$, Thermal conductivity $\lambda=0.2$ $\mathrm{W} \cdot \mathrm{m}^{-1} \cdot \mathrm{K}^{-1}$.

The ambient temperature of previous work was used in this simulation. Table I shows the hourly ambient temperature.

\section{B. The Ground Cover}

This research simulates the performance of EAHE under 6 ground covers. This simulation depends on the properties of ground cover materials. The data are illustrated in Table II.

TABLE II: THE PROPERTIES OF GROUND COVER MATERIAL

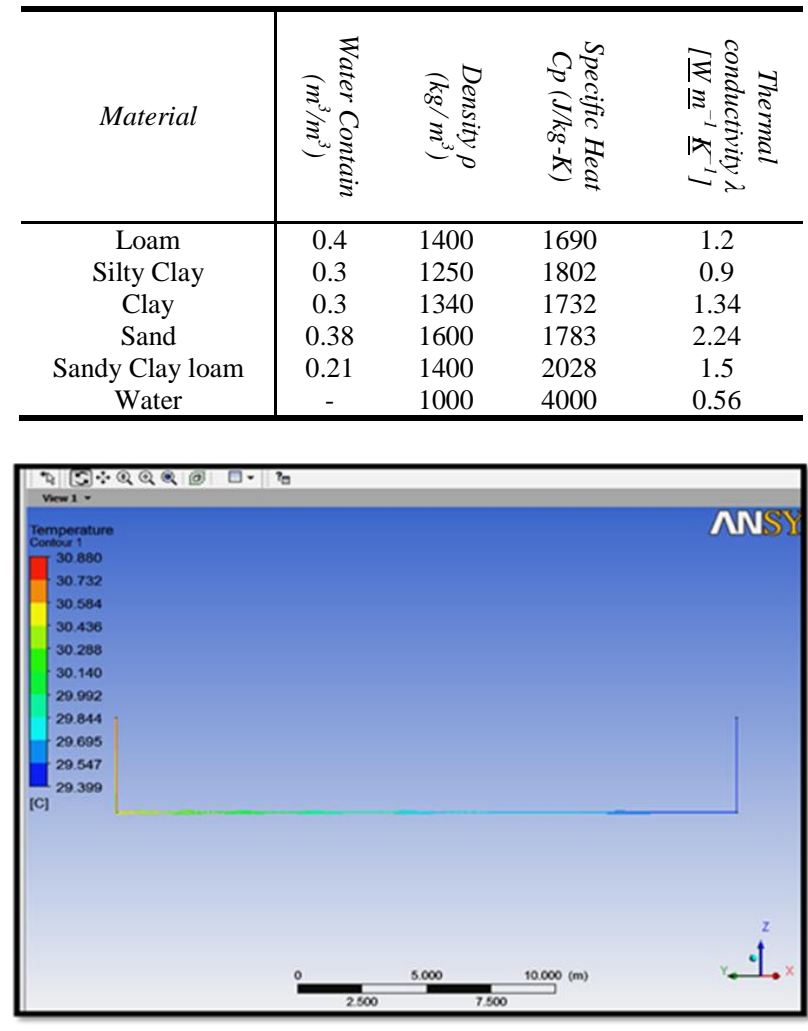

Fig. 3. Temperature distribution along symmetry plane.

\section{Thermal Model of Earth Air Heat Exchanger (EAHE)}

Building a thermal model in ANSYS Fluent involves several stages. These stages begin by choosing fluent flow from list of analysis models, constructing (EAHE) system, Meshing, setting up, illustrating solution and finally results.

The first stage is to generate the geometry of EAHE system. In this research the EAHE system consists of $50 \mathrm{~m}$ length of 3-inch diameter pipe buried at $4 \mathrm{~m}$ depth

After generating the geometry, the surfaces of the geometry have to be nominated, which means determining the inlet surface, outlet surface and wall.

Inlet refers to the input of (EAHE) system where the ambient air will flow through pipe. The outlet refers to the output of (EAHE) system directly to room or to AHU unit. Wall refers to the pipe wall where heat transfer will occur.

Meshing process will be run through coarse size of meshing. This selection is suitable for simple geometry and it also save processing time.

After choosing the energy model, it is important to set up the boundary condition where the system main components 
will be defined and its value will be fixed. Such as inlet, outlet, interior soil and pipe. To run calculation, choosing the number of iterations is required. Finally, when the calculation process finish, it is possible to illustrate the results in different forms as shown in Fig. 3.

The simulation result in its original form is less informative. It is essential to transform these results into table then into graphs in a format suitable for its intended use. In this case, the important variable is outlet temperature $T_{\mathrm{o}}$. Table III shows outlet temperature $T_{\mathrm{o}}$ of different ground covers.

TABLE III: THE TEMPERATURE OF OUTLET IN EAHE MODEL By ANSYS FLUENT

\begin{tabular}{|c|c|c|c|c|c|c|}
\hline \multirow[b]{2}{*}{ ق马 } & \multirow[b]{2}{*}{ 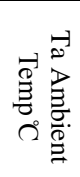 } & \multicolumn{5}{|c|}{ To Outlet Temp ${ }^{\circ} \mathrm{C}$} \\
\hline & & $\begin{array}{l}5 \\
\stackrel{0}{3}\end{array}$ & $\begin{array}{l}\mathscr{\varkappa} \\
\stackrel{\tilde{E}}{2}\end{array}$ & 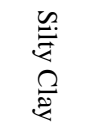 & $\stackrel{\Omega}{\ddot{\varkappa}}$ & 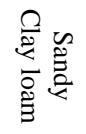 \\
\hline 1 & 26.64 & 28.53 & 28.945 & 28.256 & 28.604 & 28.704 \\
\hline 2 & 26.48 & 28.50 & 28.950 & 28.193 & 28.568 & 28.679 \\
\hline 3 & 26.15 & 28.41 & 28.900 & 28.083 & 28.501 & 28.615 \\
\hline 4 & 25.69 & 28.297 & 28.857 & 27.925 & 28.421 & 28.531 \\
\hline 5 & 25.19 & 28.11 & 28.737 & 27.743 & 28.272 & 28.366 \\
\hline 6 & 25.06 & 28.13 & 28.793 & 27.733 & 28.291 & 28.390 \\
\hline 7 & 25.10 & 28.14 & 28.784 & 27.745 & 28.299 & 28.371 \\
\hline 8 & 25.16 & 28.15 & 28.797 & 27.763 & 28.310 & 28.411 \\
\hline 9 & 26.58 & 26.58 & 26.579 & 26.581 & 26.581 & 26.581 \\
\hline 10 & 28.71 & 29.04 & 29.248 & 29.091 & 29.201 & 29.055 \\
\hline 11 & 30.88 & 29.67 & 29.371 & 29.746 & 29.584 & 29.515 \\
\hline 12 & 32.08 & 29.95 & 29.479 & 30.225 & 29.895 & 29.802 \\
\hline 13 & 32.68 & 30.08 & 29.542 & 30.426 & 30.008 & 29.901 \\
\hline 14 & 33.28 & 30.22 & 29.616 & 30.619 & 30.131 & 30.006 \\
\hline 15 & 33.19 & 30.20 & 29.599 & 30.586 & 30.113 & 29.996 \\
\hline 16 & 32.75 & 30.10 & 29.548 & 30.446 & 30.027 & 29.915 \\
\hline 17 & 32.29 & 30.00 & 29.507 & 30.294 & 29.935 & 29.832 \\
\hline 18 & 31.66 & 29.86 & 29.436 & 30.082 & 29.810 & 29.717 \\
\hline 19 & 30.96 & 29.69 & 29.382 & 29.779 & 29.617 & 29.537 \\
\hline 20 & 30.26 & 29.49 & 29.304 & 29.509 & 29.396 & 29.38 \\
\hline 21 & 29.19 & 29.11 & 29.301 & 29.133 & 29.190 & 29.101 \\
\hline 22 & 27.95 & 28.90 & 29.116 & 28.785 & 28.949 & 28.920 \\
\hline 23 & 26.69 & 28.56 & 28.981 & 28.278 & 28.611 & 28.714 \\
\hline 24 & 26.08 & 28.39 & 28.899 & 28.051 & 28.490 & 28.601 \\
\hline
\end{tabular}

\section{RESULTS AND DISCUSSION}

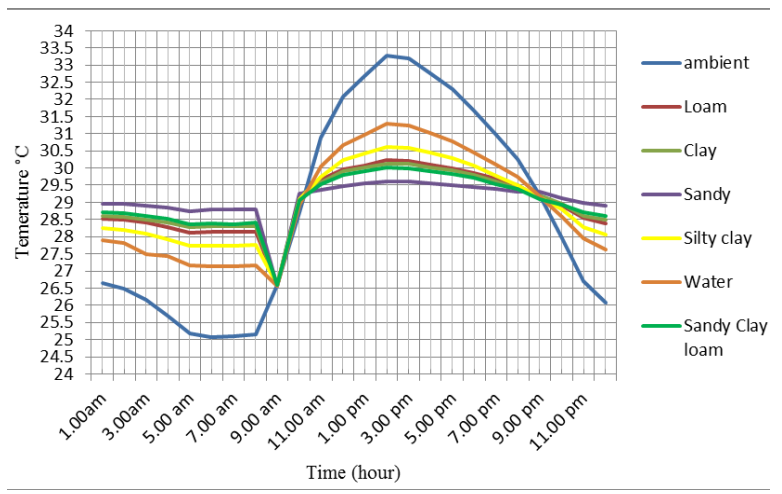

Fig. 4. the outlet temperature of EAHE system with different cover materials.

Fig. 4 shows ambient temperature and the outlet temperatures of EAHE system with different cover materials. It can be seen outlet temperature are lower than ambient temperature between around 11.00 am and $9.00 \mathrm{pm}$. This is the range of time in which EAHE may be used for cooling.

Fig. 5 compares the cooling potential $(\Delta \mathrm{T})$ for different cover materials during this time. The figure shows the maximum cooling potential $(\Delta \mathrm{T})$ occurs at $2.00 \mathrm{pm}$ for all cover' materials.

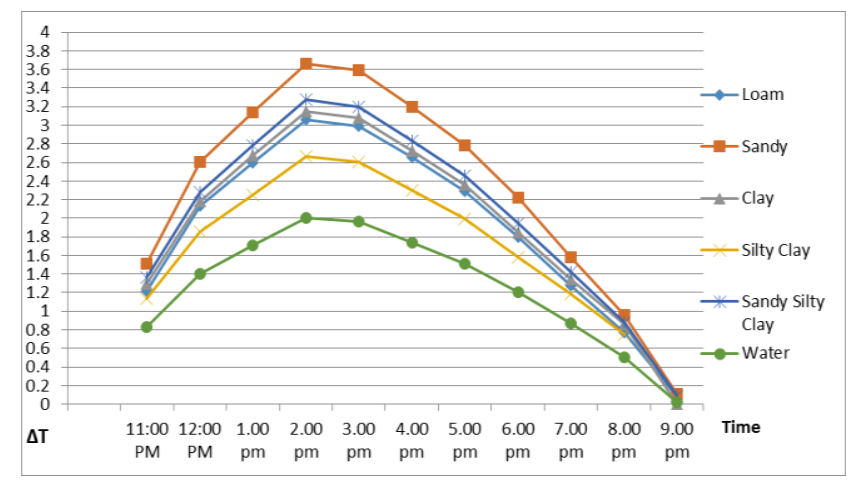

Fig. 5. Effect of Ground Cover on cooling potential $(\Delta \mathrm{T})$.

The comparison of cooling potential $(\Delta \mathrm{T})$ different ground cover materials can be seen obviously in Fig. 6. The Cooling potential $(\Delta \mathrm{T})$ of Ground Cover is compared at $2.00 \mathrm{pm}$ where the best cover is sandy soil followed by sandy clay loam, clay, loam and silty clay soil

This main reason of these results can be explained up to the thermal conductivity of these ground cover materials that sandy cover has the highest value $\lambda=2.24\left[\mathrm{~W} \cdot \mathrm{m}^{-1} \cdot \mathrm{K}^{-1}\right]$. Same thing for Sandy Clay Loam $\lambda=1.5\left[\mathrm{~W} . \mathrm{m}^{-1} . \mathrm{K}^{-1}\right]$, Clay $\lambda=1.34$ $\left[\mathrm{W} \cdot \mathrm{m}^{-1} \cdot \mathrm{K}^{-1}\right]$, Loam $\lambda=1.2\left[\mathrm{~W} \cdot \mathrm{m}^{-1} \cdot \mathrm{K}^{-1}\right]$, Silty Clay $\lambda=0.9$ $\left[\mathrm{W} . \mathrm{m}^{-1} \cdot \mathrm{K}^{-1}\right]$ and water $\lambda=0.56\left[\mathrm{~W} \cdot \mathrm{m}^{-1} \cdot \mathrm{K}^{-1}\right]$. So as we find through literature review that the main factor of ground cover material is thermal conductivity which conducts the EAHE system proficiency.

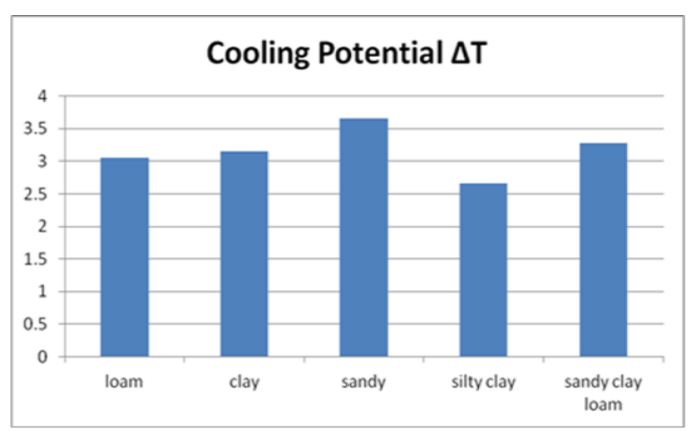

Fig. 6. Cooling potential $(\Delta \mathrm{T})$ of Ground Cover materials at $2.00 \mathrm{pm}$.

It is obvious that the all cover materials have same period of positive $\Delta \mathrm{T}$ value which extend from $11 \mathrm{am}$ until $7 \mathrm{pm}$ with reduction amount from $1{ }^{\circ} \mathrm{C}$ to $3.5^{\circ} \mathrm{C}$. this period considers as peak time of energy consumption through air condition system in Malaysia. The reduction of operation temperature with $1.9^{\circ} \mathrm{C}$ will cause reducing cooling energy load by about $595 \mathrm{kWh}$ [12]. Therefore, by using one of these ground cover materials it is possible to decrease the cooling energy load approximately from $313 \mathrm{kWh}$ to $1096 \mathrm{kWh}$.

\section{CONCLUSION AND FUTURE WORK}

This study aimed to simulate the thermal performance of Earth Air Heat Exchange system based on previous experimental layout. The study also sought to point out the role of ground cover materials to enhance the capacity of thermal performance of (EAHE). Through simulation it was found sandy soil is the best ground cover in Malaysian climate. It followed by sandy clay loam, clay, loam and silty 
clay soil.

This finding can be utilized as useful reference for the selection of the implementation location, or to use the best cover material as backfill material for buried pipes of (EAHE).

There are some modeling limitations during this research which may not have significant effects on the final result. First, it is the assumption that air flow inside the pipe is linear and there is no trouble flow especially in elbow area.

Second, is the elimination the consumed energy by blow fan in system and considering this technology as passive technique, that this energy it is not so big as what can be maintain of energy through decreasing cooling energy by pre-cooling stage.

More detailed studies about the soil properties in Malaysia are required to support better understanding of the impact of cover material to improve (EAHE) performance as passive technology in buildings. Also to carry out more experimental and numerical investigations for different locations and different parameters which enhance better understanding of the implementation of (EAHE) system in Malaysian climate.

\section{REFERENCES}

[1] M. Kepes, S. Brum, J. Vaz, M. Computacional, U. Federal, G. Furg, R. Grande, and R. Grande, "Numerical investigation about the improvement of the thermal potential of an Earth-Air Heat Exchanger (EAHE) employing the constructal design method," vol. 80, pp. 538-551, 2015.

[2] M. A. Kamal, "An overview of passive cooling techniques in buildings: Design Concepts and Architectural Interventions," vol. 55, no. 1, 2012.

[3] S. M. Sood, K. H. Chua, and L. Y. Peng, "Sustainable development in the building sector: Green building framework in Malaysia," pp. 1-8.

[4] N. B. Huat and Z. Abidin, "An overview of Malaysia Green Technology Corporation Office Building: A showcase energy-efficient building project in Malaysia," vol. 4, no. 5, pp. 212-228, 2011.

[5] M. P. Mohammadi, "Sustainability development; Energy efficiency passive design practices," vol. 3, no. 1, pp. 121-125, 2013.

[6] M. R. Alam, "Energy efficient green building based on geo cooling system in sustainable construction," vol. 3, no. 2, pp. 96-105, 2012.

[7] C. C. Taljaard, "Is passive cooling by means of earth air heat exchange effective in Pretoria?" CPD 710 Systems and Materials, 2012.

[8] R. S. Brum and L. A. O. Rocha, "Development of simplified numerical model for evaluation of the influence of soil - air heat exchanger installation depth over its thermal potential," vol. 1, pp. 506-514, 2012

[9] H. Li, Y. Yu, F. Niu, M. Sha, and B. Chen, "Performance of a coupled cooling system with earth-to-air heat exchanger and solar chimney," vol. 62 , pp. 468-477, 2014.

[10] M. De Paepe and A. Janssens, "Thermo-hydraulic design of earth-air heat exchangers," vol. 35, pp. 389-397, 2003.

[11] O. Ozgener, L. Ozgener, and J. W. Tester, "Three heating seasons monitoring of usage of low enthalpy geothermal resources : Exergetic performance analysis of an eahe," 2013.

[12] M. Zukowski, B. Sadowska, and W. Sarosiek, "Assessment of the cooling potential of an earth-tube heat exchanger in residential buildings," pp. 830-834, 2011.

[13] A. K. Zaki, A. Amjad, and A. Almssad, "Cooling by underground earth tubes," vol. 1, pp. 517-520, September 2007.

[14] M. Benhammou, B. Draoui, M. Zerrouki, and Y. Marif, "Performance analysis of an earth-to-air heat exchanger assisted by a wind tower for passive cooling of buildings in arid and hot climate," Energy Convers. Manag., vol. 91, pp. 1-11, 2015.

[15] A. R. O. Alghannam, "Investigations of Performance of Earth Tube Heat Exchanger of Sandy Soil in Hot Arid," vol. 8, no. 6, pp. 3044-3052, 2012.

[16] N. Naili, M. Hazami, I. Attar, and A. Farhat, "Assessment of surface geothermal energy for air conditioning in northern Tunisia : Direct test and deployment of ground source heat pump system," Energy Build., vol. 111, pp. 207-217, 2016.

[17] S. Mongkon, S. Thepa, P. Namprakai, and N. Pratinthong, "Cooling performance assessment of horizontal earth tube system and effect on planting in tropical greenhouse," Energy Convers. Manag., vol. 78, pp.

\section{5-236, 2014}

[18] U. Air and T. Systems, "Use of underground air tunnels for heating and cooling agricultural and residential buildings," no. 1, pp. 1-4, 1993.

[19] V. Bansal, R. Misra, G. Das Agrawal, and J. Mathur, "Performance analysis of earth-pipe-air heat exchanger for summer cooling," vol. 42, pp. 645-648, 2010.

[20] Y. Coulibaly and E. S. Traoré, "Earth-air heat exchangers for passive air conditioning: Case study Burkina Faso," vol. 17, no. 1, pp. 21-32, 2012.

[21] G. Gan, "Dynamic interactions between the ground heat exchanger and environments in earth - air tunnel ventilation of buildings," Energy Build., vol. 85, pp. 12-22, 2014.

[22] G. Chiesa, M. Simonetti, and M. Grosso, "A 3-field earth-heat-exchange system for a school building in Imola, Italy: Monitoring results," Renew. Energy, vol. 62, pp. 563-570, 2014.

[23] I. Sarbu and C. Sebarchievici, "General review of ground-source heat pump systems for heating and cooling of buildings," Energy Build., vol. 70, pp. 441-454, 2014.

[24] R. K. Singh, H. R. Murty, S. K. Gupta, and A. K. Dikshit, "An overview of sustainability assessment methodologies," Ecol. Indic., vol. 9, no. 2, pp. 189-212, 2009.

[25] S. Kumar, M. Pandey, and V. Nath, "Ground coupled heat exchangers: A review and applications," Renew. Sustain. Energy Rev., vol. 47, pp. 83-92, 2015.

[26] K. Jílková, "Use of energy of the earth for heating and cooling in buildings," pp. 75-80.

[27] D. Yang and J. Zhang, "Theoretical assessment of the combined effects of building thermal mass and earth - air-tube ventilation on the indoor thermal environment," Energy Build., vol. 81, pp. 182-199, 2014.

[28] S. Jakhar, R. Misra, V. Bansal, and M. S. Soni, "Thermal performance investigation of earth air tunnel heat exchanger coupled with a solar air heating duct for northwestern India," Energy Build., vol. 87, pp 360-369, 2015.

[29] F. Ascione, L. Bellia, and F. Minichiello, "Earth-to-air heat exchangers for Italian climates," vol. 36, 2011.

[30] A. Sehli, A. Hasni, and M. Tamali, "The potential of earth-air heat exchangers for low energy cooling of buildings in South Algeria," vol. 18, pp. 496-506, 2012.

[31] T. S. Bisoniya, A. Kumar, and P. Baredar, "Energy metrics of earth-air heat exchanger system for hot and dry climatic conditions of India," Energy Build., vol. 86, pp. 214-221, 2015.

[32] J. Xamán, J. Arce, and G. Álvarez, "Numerical study of earth-to-air heat exchanger for three different climates," Energy Build., vol. 76, pp. 238-248, 2014.

[33] K. H. Lee and R. K. Strand, "Implementation of an earth tube system."

[34] H. Demir, S. Ö. Atayılmaz, and Ö. Ağra, "Experimental ground source heat pump system to investigate heat transfer in soil," pp. 1352-1359.

[35] F. Niu, Y. Yu, D. Yu, and H. Li, "Heat and mass transfer performance analysis and cooling capacity prediction of earth to air heat exchanger," Appl. Energy, vol. 137, pp. 211-221, 2015.

[36] S. Kim, Y. J. Jang, Y. Shin, and G. Kim, "Economic feasibility analysis of the application of geothermal energy facilities to public building structures," pp. 1667-1685, 2014

[37] R. P. Moldovan, "Diminishing energy consumption in heating and cooling passive houses using geothermal energy rezumat," vol. 55, no. 3, 2012.

[38] R. Wagner, S. Beisel, A. Spieler, K. Vajen, and A. Gerber, "No title," pp. 1-7, 2000.

[39] Y. Song, Y. Yao, W. Na, D. Candidate, and D. Candidate, "Impacts of soil and pipe thermal conductivity on performance of horizontal pipe in a ground-source heat pump," no. 2, pp. 2-7, 2006

[40] A. N. Sanusi and Zafirah, "Low energy ground cooling system for buildings in hot and humid," Malaysia by aliyah nur zafirah sanusi B. Sc., B. Arch., M. Phil. Thesis, June 2012.

[41] A. Debbarma, "Performance of proposed earth-tank heat exchanger: A computational study," vol. 3, no. 1, pp. 68-72, 2013.

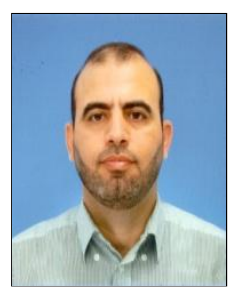

Haitham Alkhalaf was born in Aleppo, Syria in 1981. He had a bachelor degree of mechanical engineering at Aleppo city, Syria in 2004; master of building services engineering at International Islamic University, Kuala Lumpur, Malaysia in 2014.

His first work experience was as maintenance engineer in different companies of governmental and private sectors. During his $\mathrm{PhD}$ degree, he works as a research assistance and teaching assistance of Keio University, Japan.

Mr. Alkhalaf has a membership in Engineering society of Syria. 